\title{
Thermosinus carboxydivorans gen. nov., sp. nov., a new anaerobic, thermophilic, carbon-monoxide- oxidizing, hydrogenogenic bacterium from a hot pool of Yellowstone National Park
}

\section{Correspondence \\ Tatyana G. Sokolova tatso@mail.ru}

\author{
Tatyana G. Sokolova, ${ }^{1}$ Juan M. González, ${ }^{2 \dagger}$ \\ Nadezhda A. Kostrikina, ${ }^{1}$ Nikolai A. Chernyh, ${ }^{1}$ \\ Tatiana V. Slepova, ${ }^{1}$ Elizaveta A. Bonch-Osmolovskaya ${ }^{1}$ \\ and Frank T. Robb² \\ 'Institute of Microbiology, Russian Academy of Sciences, Prospect 60 Let Oktyabrya, 7/2, \\ 117811 Moscow, Russia \\ ${ }^{2}$ COMB, Columbus Center, 701 E. Pratt St, Baltimore, MD 21202, USA
}

A new anaerobic, thermophilic, facultatively carboxydotrophic bacterium, strain Nor $1^{\top}$, was isolated from a hot spring at Norris Basin, Yellowstone National Park. Cells of strain Nor $1^{\top}$ were curved motile rods with a length of $2 \cdot 6-3 \mu \mathrm{m}$, a width of about $0.5 \mu \mathrm{m}$ and lateral flagellation. The cell wall structure was of the Gram-negative type. Strain Nor $1^{\top}$ was thermophilic (temperature range for growth was $40-68^{\circ} \mathrm{C}$, with an optimum at $\left.60^{\circ} \mathrm{C}\right)$ and neutrophilic $(\mathrm{pH}$ range for growth was $6 \cdot 5-7 \cdot 6$, with an optimum at 6·8-7·0). It grew chemolithotrophically on $\mathrm{CO}$ (generation time, $1 \cdot 15 \mathrm{~h}$ ), producing equimolar quantities of $\mathrm{H}_{2}$ and $\mathrm{CO}_{2}$ according to the equation $\mathrm{CO}+\mathrm{H}_{2} \mathrm{O} \rightarrow \mathrm{CO}_{2}+\mathrm{H}_{2}$. During growth on $\mathrm{CO}$ in the presence of ferric citrate or amorphous ferric iron oxide, strain Nor $1^{\top}$ reduced ferric iron but produced $\mathrm{H}_{2}$ and $\mathrm{CO}_{2}$ at a ratio close to $1: 1$, and growth stimulation was slight. Growth on $\mathrm{CO}$ in the presence of sodium selenite was accompanied by precipitation of elemental selenium. Elemental sulfur, thiosulfate, sulfate and nitrate did not stimulate growth of strain $\mathrm{Nor}^{\top}{ }^{\top}$ on $\mathrm{CO}$ and none of these chemicals was reduced. Strain Nor $1^{\top}$ was able to grow on glucose, sucrose, lactose, arabinose, maltose, fructose, xylose and pyruvate, but not on cellobiose, galactose, peptone, yeast extract, lactate, acetate, formate, ethanol, methanol or sodium citrate. During glucose fermentation, acetate, $\mathrm{H}_{2}$ and $\mathrm{CO}_{2}$ were produced. Thiosulfate was found to enhance the growth rate and cell yield of strain Nor $1^{\top}$ when it was grown on glucose, sucrose or lactose; in this case, acetate, $\mathrm{H}_{2} \mathrm{~S}$ and $\mathrm{CO}_{2}$ were produced. In the presence of thiosulfate or ferric iron, strain Nor $1^{\top}$ was also able to grow on yeast extract. Lactate, acetate, formate and $\mathrm{H}_{2}$ were not utilized either in the absence or in the presence of ferric iron, thiosulfate, sulfate, sulfite, elemental sulfur or nitrate. Growth was completely inhibited by penicillin, ampicillin, streptomycin, kanamycin and neomycin. The DNA $\mathrm{G}+\mathrm{C}$ content of the strain was $51 \cdot 7 \pm 1 \mathrm{~mol} \%$. Analysis of the $16 \mathrm{~S}$ rRNA gene sequence revealed that strain Nor $1^{\top}$ belongs to the Bacillus-Clostridium phylum of the Gram-positive bacteria. On the basis of the studied phenotypic and phylogenetic features, we propose that strain Nor $1^{\top}$ be assigned to a new genus, Thermosinus gen. nov. The type species is Thermosinus carboxydivorans sp. nov. (type strain, Nor1 ${ }^{\top}=\mathrm{DSM} 14886^{\top}=\mathrm{VKM} \mathrm{B}-2281^{\top}$ ).
Published online ahead of print on 9 July 2004 as DOI 10.1099/ ijs.0.63186-0.

tPresent address: Instituto de Recursos Naturales y Agrobiologia, CSIC, PO Box 1052, 41080 Sevilla, Spain.

The GenBank/EMBL/DDBJ accession number for the 16S rRNA gene sequence of strain $\mathrm{Nor}^{\top}{ }^{\top}$ is AY519200.

\section{INTRODUCTION}

Several phylogenetically diverse thermophilic prokaryotes perform the metabolic reaction $\mathrm{CO}+\mathrm{H}_{2} \mathrm{O} \rightarrow \mathrm{CO}_{2}+\mathrm{H}_{2}$ $\left(\Delta G^{0}=-20 \mathrm{~kJ}\right)$. These are representatives of the bacterial genera Carboxydothermus (Svetlichny et al., 1991, 1994), Caldanaerobacter (formerly Carboxydibrachium pacificum) 
(Sokolova et al., 2001; Fardeau et al., 2004) and Carboxydocella (Sokolova et al., 2002). Recently, a hyperthermophilic archaeon of the genus Thermococcus capable of growth at the expense of the same reaction was isolated from deepsea hydrothermal vents (Sokolova et al., 2004). The metabolism of Carboxydothermus hydrogenoformans has been studied at the enzymic level (Svetlitchny et al., 2001; Dobbek et al., 2001). This physiological group of prokaryotes has been proposed to be named 'hydrogenogens' (Svetlitchny et al., 2001). CO-oxidizing hydrogenogenic prokaryotes were shown to possess various metabolic capacities. Growth of Carboxydocella thermautotrophica was found to be obligately dependent on CO. Apart from growth on CO, Carboxydothermus hydrogenoformans is able to grow on pyruvate (Pusheva \& Sokolova, 1995). Caldanaerobacter subterraneus subsp. pacificus, isolated from a deep-sea hydrothermal vent in the Okinawa Trough, besides having the capacity for anaerobic $\mathrm{CO}$ oxidation $/ \mathrm{H}_{2}$ formation, is capable of growing on several fermentable substrates (Sokolova et al., 2001). Thermococcus strain AM4 grows on $\mathrm{CO}$ producing $\mathrm{H}_{2}$, or chemo-organotrophically with elemental sulfur (Sokolova et al., 2004). Herein, we report the isolation of a novel anaerobic, $\mathrm{CO}$-utilizing, $\mathrm{H}_{2}$ producing, thermophilic bacterium capable of iron reduction during growth on $\mathrm{CO}$.

\section{METHODS}

Collection of samples. A sample of mud and water was taken from a small pool in the neutral (wooded) part of Norris Basin in the Yellowstone National Park. Organic matter (rotting wood, scum) was present in the pool. The geographical coordinates of the sampling site were $44^{\circ} 43 \cdot 797 \mathrm{~N}, 110^{\circ} 42 \cdot 506 \mathrm{~W}$. The sample temperature was $50{ }^{\circ} \mathrm{C}$ and its $\mathrm{pH}$ was $7 \cdot 5$ (at $50{ }^{\circ} \mathrm{C}$ ).

Culture conditions and strains. Enrichment and isolation of anaerobic carboxydotrophic bacteria were carried out on Medium 1 supplemented with a neutralized solution of ferric citrate or amorphous ferric iron oxide. Medium 1 was of the following composition $\left(\mathrm{g} \mathrm{l}^{-1}\right): \mathrm{NH}_{4} \mathrm{Cl}, 1 ; \mathrm{MgCl}_{2} \cdot 2 \mathrm{H}_{2} \mathrm{O}, 0 \cdot 33 ; \mathrm{CaCl}_{2} \cdot 6 \mathrm{H}_{2} \mathrm{O}, 0 \cdot 1 ; \mathrm{KCl}, 0 \cdot 33$; $\mathrm{KH}_{2} \mathrm{PO}_{4}, 0.5 ; 1 \mathrm{ml}$ of trace element solution (Kevbrin \& Zavarzin, 1992); $1 \mathrm{ml}$ of vitamin solution (Wolin et al., 1963). After boiling, the medium was cooled under an $\mathrm{N}_{2}$ atmosphere. Yeast extract $\left(0 \cdot 2 \mathrm{~g} \mathrm{l}^{-1}\right)$ and $\mathrm{NaHCO}_{3}\left(0 \cdot 5 \mathrm{~g} \mathrm{l}^{-1}\right)$ were added afterwards, and the $\mathrm{pH}$ was adjusted to $6 \cdot 8-7 \cdot 0$ with $6 \mathrm{M} \mathrm{HCl}$. A neutralized solution of ferric citrate or amorphous ferric iron oxide was added to a final concentration of 20 or $90 \mathrm{mM}$, respectively. Amorphous ferric iron oxide was prepared by titrating a solution of $\mathrm{FeCl}_{3}$ with $10 \% \mathrm{NaOH}$ to $\mathrm{pH}$ 9. Aliquots $(10 \mathrm{ml})$ of the medium were placed in $50 \mathrm{ml}$ bottles, and the head-space was filled with $\mathrm{CO}(100 \mathrm{kPa})$. Pure cultures were obtained from colonies on the same medium solidified with $5 \%$ agar in roll-tubes under $\mathrm{CO}$ in the gas phase. Growth of pure cultures and physiological tests were performed using Medium 2. Medium 2 had the same composition as Medium 1 except it was supplemented with $\mathrm{Na}_{2} \mathrm{~S} .9 \mathrm{H}_{2} \mathrm{O}\left(0 \cdot 5 \mathrm{~g} \mathrm{l}^{-1}\right)$.

The reference strains used in this study were Carboxydothermus hydrogenoformans Z-2901 ${ }^{\mathrm{T}}$ (DSM 6008 ${ }^{\mathrm{T}}$ ) (Svetlichny et al., 1991), Carboxydocella thermautotrophica $41^{\mathrm{T}}$ (DSM $12326^{\mathrm{T}}$ ) (Sokolova et al., 2002) and Caldanaerobacter subterraneus subsp. pacificus JM ${ }^{\mathrm{T}}$ (DSM $12653^{\mathrm{T}}$ ) (Sokolova et al., 2001; Fardeau et al., 2004).

Light and electron microscopy. Light microscopy was carried out using a phase-contrast microscope with a 90/1-25 oil immersion objective. Specimens of whole cells for electron microscopy were negatively stained with $2 \%$ phosphotungstic acid. For the preparation of thin sections, cells were fixed with $5 \%$ glutaraldehyde for $2 \mathrm{~h}$ and $1 \% \mathrm{OsO}_{4}$ for $4 \mathrm{~h}$ at $4{ }^{\circ} \mathrm{C}$ and then embedded in Epon-812. The thin sections were stained with uranyl acetate and lead citrate. Electron micrographs were taken with a JEM-100C electron microscope.

Physiological studies. To test the growth of the novel isolate with various substrates and electron acceptors, Medium 2 with $100 \% \mathrm{~N}_{2}$ in the gas phase was used, supplemented with the following substrates $\left(2 \mathrm{~g} \mathrm{l}^{-1}\right)$ : peptone, yeast extract, sucrose, lactose, glucose, galactose, ethanol, methanol, sodium salts of citrate, acetate, formate or pyruvate. Possible electron acceptors - elemental sulfur $\left(10 \mathrm{~g} \mathrm{l}^{-1}\right)$ and sodium salts of nitrate, sulfate, thiosulfate $\left(2 \mathrm{~g} \mathrm{l}^{-1}\right)$, sulfite $(2 \mathrm{mM})$ or selenate $(2 \mathrm{mM})$ - were tested on Medium 2 with various growth substrates. Growth with amorphous ferric iron oxide $(90 \mathrm{mM})$ or selenite $(2 \mathrm{mM})$ on various substrates was tested in Medium 1.

Bacterial growth was determined by direct cell count under a phasecontrast microscope.

Determinations of CO, gaseous products of metabolism, short-chain organic acids and alcohols were performed by GC as described previously (Sokolova et al., 2001). $\mathrm{H}_{2} \mathrm{~S}$ was determined by colorimetric reaction (Trüper \& Schlegel, 1964). Fe(III) reduction was determined by measuring the accumulation of $\mathrm{Fe}(\mathrm{II})$ in the growth medium. For that, a $0.5 \mathrm{ml}$ sample was added to $5 \mathrm{ml}$ of $0.6 \mathrm{M} \mathrm{HCl}$ and, after a $24 \mathrm{~h}$ extraction, $\mathrm{HCl}$-soluble $\mathrm{Fe}(\mathrm{II})$ was determined by the reaction with 2,2'-dipyridyl (Balashova \& Zavarzin, 1980).

DNA isolation and base composition. DNA was prepared as described by Marmur (1961). The DNA G + C content was determined by melting-point analysis (Marmur \& Doty, 1962) using Escherichia coli $\mathrm{K}-12 \mathrm{DNA}$ as a reference.

rRNA gene sequence. The $16 \mathrm{~S}$ rRNA gene sequence was PCRamplified by using the primer pair 519F ( $5^{\prime}$-GTT TCA GCM GCC GCG GTA ATW C-3') and 1522R (5'-AAG GAG GTG ATC CAG CCG CA-3'). The amplified DNA fragment was purified using the Qiagen PCR purification kit (Qiagen) and sequenced by the dideoxynucleotide chain-termination method on an $\mathrm{ABI} 373 \mathrm{~A}$ sequencer (Applied Biosystems). Sequencing was performed using the primers 519F and 341F (5'-CC TAC GGG AGG CAG CAG-3'), forward strand, and primers 907R (5'-CCC CGT CAA TTC ATT TGA GTT $\left.\mathrm{T}-3^{\prime}\right)$ and $1522 \mathrm{R}$, reverse strand. Sequence alignment was performed using the software suite ARB (Ludwig et al., 2004). The alignment was edited manually considering the expected sequence secondary structure. An unrooted phylogenetic tree was constructed by maximum-likelihood using the program FastDNAml (Felsenstein, 1981) embedded in ARB. The obtained tree topology was reconstructed by quartet-puzzling using the program Treepuzzle (Strimmer \& von Haeseler, 1996) also available in the ARB package. The quartetpuzzling tree represented a consensus tree showing well supported branching. It was based on 1000 puzzling trials. The reliability value of each internal branch indicates as a percentage how often the corresponding cluster was found. The GenBank/EMBL/DDBJ accession numbers of the $16 \mathrm{~S}$ rRNA sequences used in this study are given in Fig. 4.

\section{RESULTS AND DISCUSION}

\section{Enrichment and isolation}

For the enrichment of anaerobic, thermophilic, COoxidizing bacteria, $100 \mathrm{ml}$ serum bottles containing $20 \mathrm{ml}$ Medium 1 with ferric citrate and $\mathrm{CO}$ as the gas phase were 
inoculated with about $1 \mathrm{~g}$ of sample. After 3 days incubation at $55^{\circ} \mathrm{C}$, the gas pressure in several bottles increased from 100 to $120-150 \mathrm{kPa}$. Growth of curved rod-shaped cells was observed. The $\mathrm{CO}$ content in the gas phase decreased; the resulting gas phase composition was about $25-30 \% \mathrm{CO}, 30 \% \mathrm{H}_{2}$ and $30 \% \mathrm{CO}_{2}$. The colour of the medium changed from yellow-brown to green, indicating the reduction of $\mathrm{Fe}(\mathrm{III})$ to $\mathrm{Fe}(\mathrm{II})$. When transferred to Medium 2, the culture retained the ability to grow by oxidation of $\mathrm{CO}$ to $\mathrm{CO}_{2}$ and production of $\mathrm{H}_{2}$ and had the same morphology. After seven passages performed by serial tenfold dilutions, the culture was transferred to solid medium in roll-tubes filled with CO. After 4 days incubation at $55-60^{\circ} \mathrm{C}$ of tubes inoculated with aliquots from the $10^{6}$ and $10^{7}$ dilutions, round white colonies of about $0.5 \mathrm{~mm}$ in diameter developed. Several colonies were isolated and transferred to Medium 2 under $100 \%$ CO. From all the colonies the growth of motile curved rods was obtained. One isolate, designated $\operatorname{Norl}^{\mathrm{T}}$, was chosen for further characterization.

\section{Morphology}

Cells of strain Nor $1^{\mathrm{T}}$ were curved rods with a length of $2 \cdot 6-3 \mu \mathrm{m}$ and a width of about $0 \cdot 5 \mu \mathrm{m}$, arranged singly or in pairs (Fig. 1a, b). Cells were motile due to lateral flagella (Fig. 1a). Electron microscopy of ultrathin sections revealed a Gram-negative cell wall structure (Fig. 1c). The outer membrane had a folded structure (Fig. 1b, c). Cells divided by binary transverse fission (Fig. 1b, c).

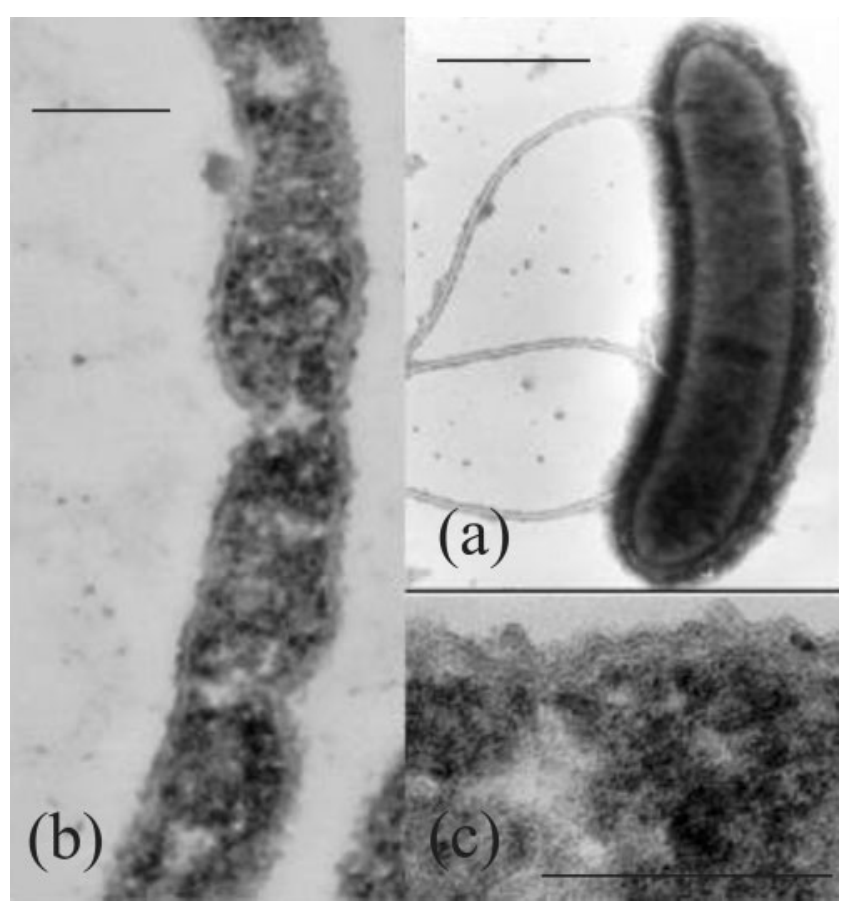

Fig. 1. Electron micrographs of cells of strain Nor1 ${ }^{\top}$. Thin sections (b, c) and negative staining of whole cells (a). Bars, $0.5 \mu \mathrm{m}$.

\section{Growth parameters}

Strain Nor $1^{\mathrm{T}}$ grew between 40 and $68^{\circ} \mathrm{C}$, with an optimum at $60{ }^{\circ} \mathrm{C}$. No growth occurred at 37 or $70^{\circ} \mathrm{C}$. Growth was possible between $\mathrm{pH} 6 \cdot 5$ and $7 \cdot 6$; no growth was detected at $\mathrm{pH} 6 \cdot 2$ or $7 \cdot 8$. Optimum $\mathrm{pH}$ for growth was $6 \cdot 8-7 \cdot 0$.

\section{Physiology of growth}

Strain Nor $1^{\mathrm{T}}$ was able to grow on Medium 1 with or without ferric iron with $100 \%$ CO in the gas phase, as well as on Medium 2 with $100 \% \mathrm{CO}$. CO oxidation was coupled with $\mathrm{H}_{2}$ and $\mathrm{CO}_{2}$ formation in equimolar quantities according to the equation $\mathrm{CO}+\mathrm{H}_{2} \mathrm{O} \rightarrow \mathrm{CO}_{2}+\mathrm{H}_{2}$ (Fig. 2 and Fig. 3). No methane, acetate or any other metabolic products were produced. The generation time of strain $\operatorname{Nor}^{\mathrm{T}}$ grown on CO without ferric iron was $1 \cdot 15 \mathrm{~h}$. During the growth on $\mathrm{CO}$ in Medium 1 in the presence of ferric citrate or amorphous ferric iron oxide, strain Nor $1^{\mathrm{T}}$ reduced ferric iron (Fig. 3); however, the amount of ferric iron reduced was not large enough to shift significantly the ratio of $\mathrm{H}_{2}$ and $\mathrm{CO}_{2}$ produced. The generation time of strain Nor1 ${ }^{\mathrm{T}}$ during growth on $\mathrm{CO}$ in the presence of ferric citrate was $1.07 \mathrm{~h}$. The isolate grew in Medium 1 on CO in the presence of selenite, reducing it to elemental selenium, visible as red precipitate, but producing $\mathrm{H}_{2}$ and $\mathrm{CO}_{2}$ in nearly equimolar quantities. The isolate did not grow under an $\mathrm{H}_{2} / \mathrm{CO}_{2}(4: 1)$ mixture either in Medium 2 or in Medium 1 supplemented with ferric citrate or amorphous ferric iron oxide.

Strain Nor $1^{\mathrm{T}}$ was found to be an obligate anaerobe. It did not grow under mixtures of $\mathrm{CO}$ and air, which contained $0 \cdot 5,1 \cdot 0,1 \cdot 5,2,5$ or $10 \%$ molecular oxygen.

On Medium 2 (reduced with sodium sulfide), strain Nor $1^{\mathrm{T}}$ was capable of growth with glucose, sucrose, lactose,

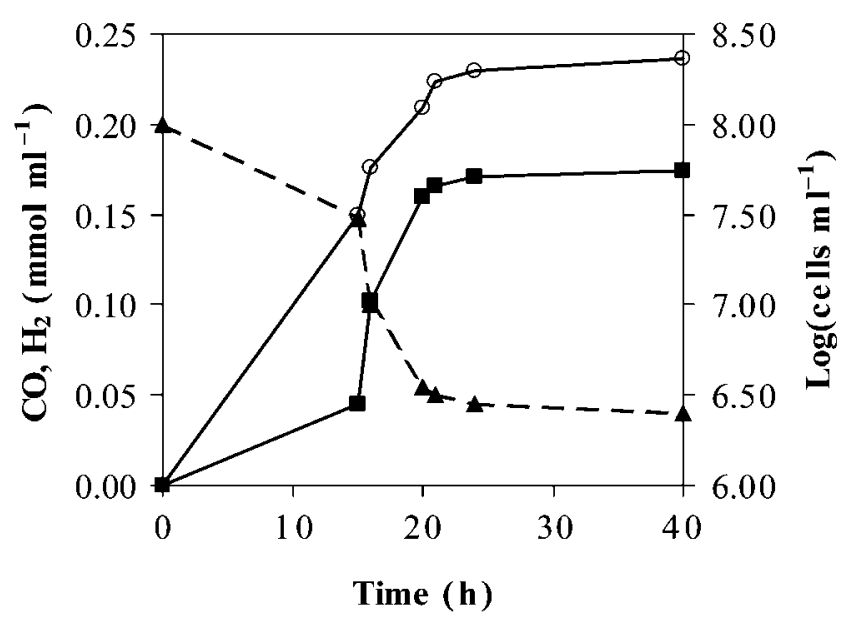

Fig. 2. Growth of strain $\operatorname{Nor} 1^{\top}$ at $60^{\circ} \mathrm{C}$ in Medium 2 supplemented with $200 \mathrm{mg}$ yeast extract $\mathrm{I}^{-1}$ under an atmosphere of $\mathrm{CO}: \bigcirc$, cell number; $\boldsymbol{\Delta}, \mathrm{CO}$ consumption; $\boldsymbol{\square}, \mathrm{H}_{2}$ production. $\mathrm{CO}$ and $\mathrm{H}_{2}$ are shown as their quantities in the gas phase per $1 \mathrm{ml}$ of liquid culture. 


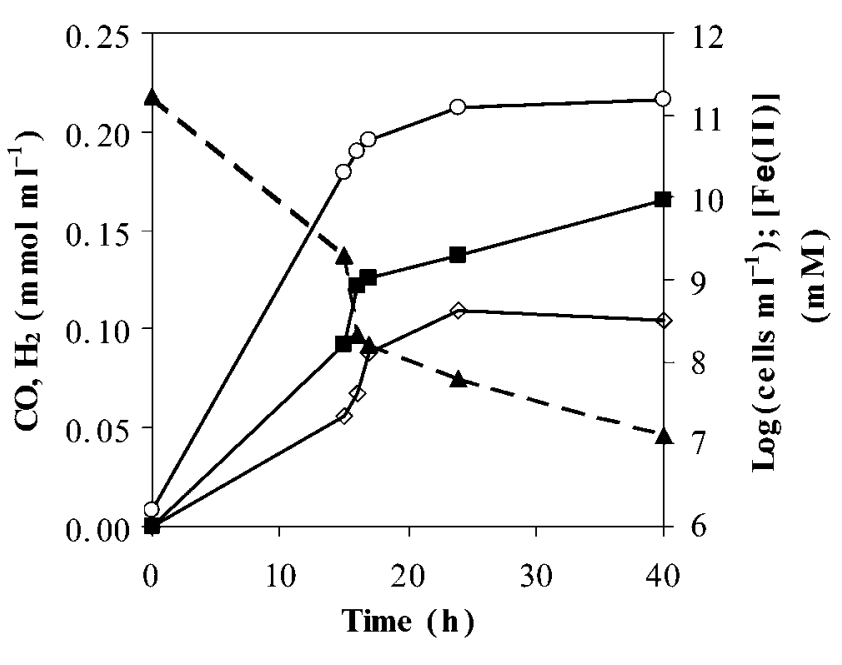

Fig. 3. Growth of strain Nor $1^{\top}$ at $60^{\circ} \mathrm{C}$ in Medium 1 supplemented with $20 \mathrm{mM}$ ferric citrate and $200 \mathrm{mg}$ yeast extract $\mathrm{I}^{-1}$ under an atmosphere of $\mathrm{CO}: \bigcirc$, cell number; $\boldsymbol{\Delta}, \mathrm{CO}$ consumption; $\mathbf{\square}, \mathrm{H}_{2}$ production; $\diamond$, ferrous iron production. $\mathrm{CO}$ and $\mathrm{H}_{2}$ are shown as their quantities in the gas phase per $1 \mathrm{ml}$ of liquid culture.

arabinose, maltose, fructose, xylose and pyruvate, but not with cellobiose, galactose, peptone, yeast extract, lactate, acetate, formate, ethanol, methanol or sodium citrate. Weak growth was detected on the medium with mannitol. During growth on glucose, strain Nor $1^{\mathrm{T}}$ produced acetate, $\mathrm{H}_{2}$ and $\mathrm{CO}_{2}$. On Medium 1 (without reduction with sodium sulfide), strain Nor $1^{\mathrm{T}}$ was able to grow on organic substrates (glucose, sucrose and lactose) only in the presence of electron acceptors (ferric iron or thiosulfate), producing ferrous iron or $\mathrm{H}_{2} \mathrm{~S}$, respectively. Thiosulfate was found to stimulate the growth rate and cell yield of strain Nor $1^{\mathrm{T}}$ on glucose. During growth on glucose in the presence of thiosulfate, $\mathrm{H}_{2}$ was not produced; the products were acetate, $\mathrm{CO}_{2}$ and $\mathrm{H}_{2} \mathrm{~S}$. No growth or $\mathrm{H}_{2} \mathrm{~S}$ production was observed on the Medium 2 with peptone, lactate or acetate, in the presence of thiosulfate. The isolate showed poor growth and weak ferrous iron formation in Medium 1 with peptone or yeast extract and amorphous ferric iron oxide. The isolate did not reduce selenite or selenate during growth on peptone, sucrose or lactose.

Nitrate, sulfite and sulfate were not reduced during growth of strain Nor $1^{\mathrm{T}}$ with CO or on organic substrates.

No growth was detected under an atmosphere of $\mathrm{H}_{2}+\mathrm{CO}_{2}$ or $\mathrm{H}_{2}+$ air.

Our tests of other hydrogenogenic carboxydotrophs, Carboxydothermus hydrogenoformans, Carboxydocella thermautotrophica and Caldanaerobacter subterraneous subsp. pacificus, for the capacity to reduce $\mathrm{Fe}(\mathrm{III})$ during growth on $\mathrm{CO}$ showed that none of these three organisms was able to reduce ferric citrate or amorphous oxide of ferric iron.

\section{Sensitivity to antibiotics}

Penicillin $\left(100 \mu \mathrm{g} \mathrm{ml}^{-1}\right)$, ampicillin $\left(100 \mu \mathrm{g} \mathrm{ml}^{-1}\right)$, streptomycin $\left(100 \mu \mathrm{g} \mathrm{ml}^{-1}\right)$, kanamycin $\left(50 \mu \mathrm{g} \mathrm{m}^{-1}\right)$ and neomycin $\left(50 \mu \mathrm{g} \mathrm{ml}^{-1}\right)$ completely inhibited CO utilization and growth of strain $\operatorname{Norl}^{\mathrm{T}}$.

\section{DNA base composition}

The DNA G+C content of strain $\operatorname{Norl}^{\mathrm{T}}$ was $51 \cdot 7 \pm 1 \mathrm{~mol} \%$.

\section{5 rRNA gene sequence analysis}

Sequencing of the $16 \mathrm{~S}$ rRNA gene from strain $\operatorname{Nor}^{\mathrm{T}}$ placed this isolate in the domain Bacteria; this is in agreement with the profile of antibiotic inhibition of growth. A BLAST search (Altschul et al., 1997) showed Dendrosporobacter quercicolus (formerly Clostridium quercicolum) (Strömpl et al., 2000) as the closest relative (89.6\% similarity). Other phyletic relatives of strain Nor $1^{\mathrm{T}}$, such as Acetonema $(88 \cdot 1 \%)$, Sporomusa $(87 \cdot 4 \%)$ and Selenomonas $(86 \cdot 2 \%)$ species, showed lower similarity values but phylogenetic analysis presented them clustered with strain $\operatorname{Nor}^{\mathrm{T}}{ }^{\mathrm{T}}$ (Fig. 4).

The ability to grow anaerobically on $\mathrm{CO}$ with the production of $\mathrm{H}_{2}$ as the only reduced product was first observed in the mesophilic purple, non-sulfur bacteria Rhodocyclus gelatinosus and Rhodospirillum rubrum (Uffen, 1976; Bonam et al., 1989). Carboxydothermus hydrogenoformans was the first anaerobic, thermophilic, non-photosynthetic bacterium found that performed this process (Svetlichny et al., 1991). Later, several other organisms performing the reaction of anaerobic $\mathrm{CO}$ oxidation with $\mathrm{CO}_{2}$ and $\mathrm{H}_{2}$ production were described (Svetlichny et al., 1994; Sokolova et al., 2001, 2004). Strain Nor $1^{\mathrm{T}}$ is similar to Caldanaerobacter subterraneus subsp. pacificus (formerly Carboxydibrachium pacificum) (Sokolova et al., 2001; Fardeau et al., 2004) in its ability to ferment some carbohydrates. However, they differ in the ability to reduce ferric iron. Strain Nor $1^{\mathrm{T}}$ differs from Caldanaerobacter subterraneus subsp. pacificus $\mathrm{JM}^{\mathrm{T}}$ also in its cell morphology: $\operatorname{Nor}^{\mathrm{T}}$ cells are short, curved, motile rods, while Caldanaerobacter subterraneus subsp. pacificus cells are non-motile, straight, long, thin rods, sometimes branching. The isolate described in this work differs from other previously described anaerobic $\mathrm{CO}$-oxidizing hydrogenogens by its capacity for fermentative growth on several carbohydrates and for thiosulfate reduction. Unlike other anaerobic $\mathrm{CO}$-oxidizing hydrogenogenic bacteria, strain $\operatorname{Nor}^{\mathrm{T}}$ is able to reduce ferric iron during the growth on $\mathrm{CO}$ in the presence of ferric citrate or ferric iron amorphous oxide. All previously described $\mathrm{CO}$-dependent, $\mathrm{H}_{2}$-generating bacteria show a cell wall structure typical of Gram-positive bacteria; they belong to the Bacillus-Clostridium phylum of Gram-positive bacteria and do not form a single phylogenetic cluster. Morphologically, strain Nor $1^{\mathrm{T}}$ resembles Thermanaerovibrio species (Baena et al., 1999; Zavarzina et al., 2000), which are thermophilic, anaerobic organotrophs with vibrioid cells. As for strain $\operatorname{Nor}^{\mathrm{T}}$, Thermanaerovibrio 


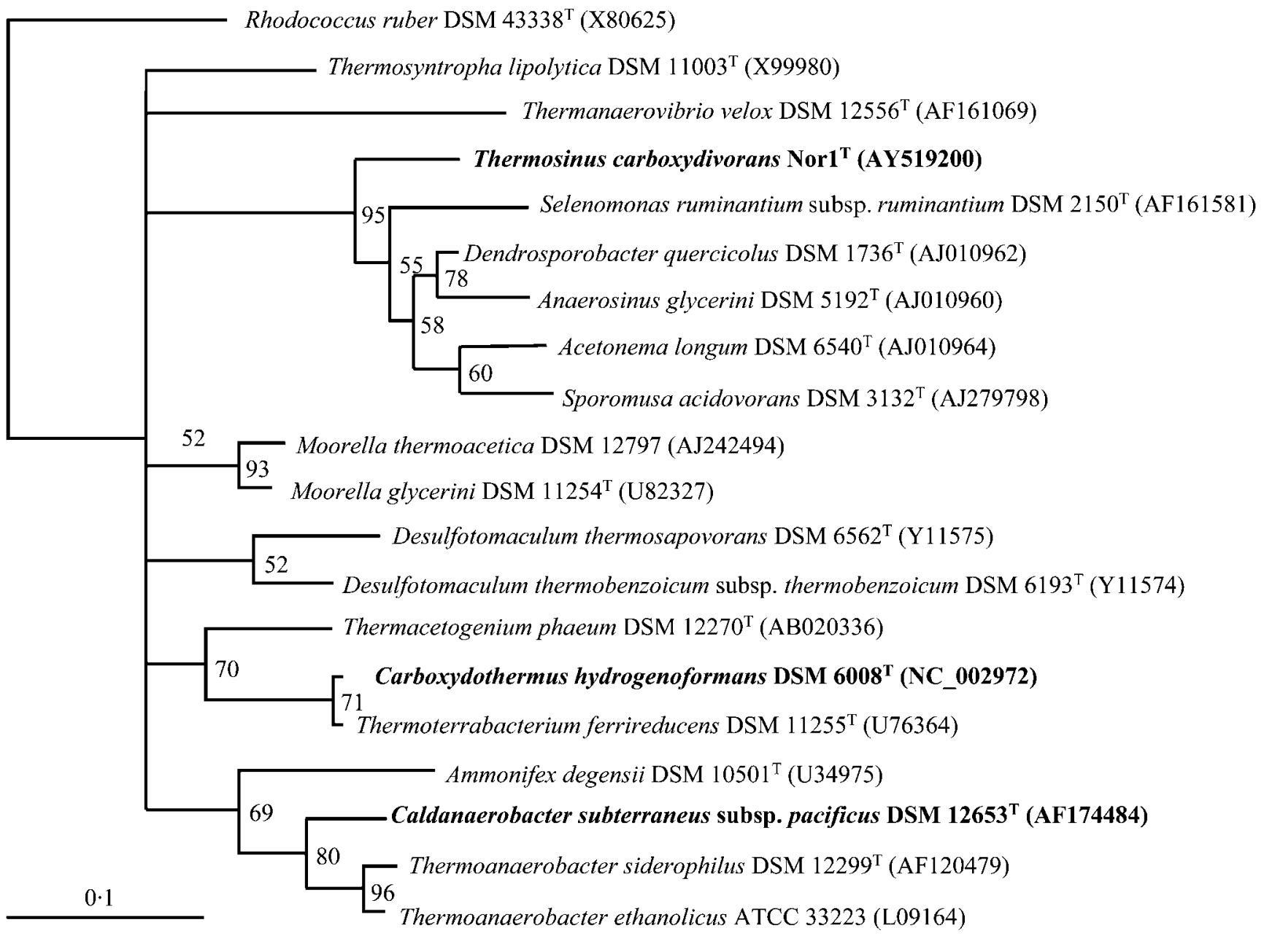

Fig. 4. Unrooted phylogenetic tree showing the position of strain Nor $1^{\top}$. The scale bar represents the expected number of changes per sequence position. Reliability values of internal branches are expressed as percentages. Hydrogenogenic carboxydotrophs are shown in bold. GenBank/EMBL/DDBJ accession numbers for the 16S rRNA gene sequences are in parentheses.

species have curved cells, which are motile by means of a tuft of lateral flagella located on the concave side of the cell, Gram-negative, non-spore-forming and capable of growing chemo-organotrophically with fermentable substrates or lithoheterotrophically with molecular hydrogen and elemental sulfur, reducing sulfur to $\mathrm{H}_{2} \mathrm{~S}$ (Zavarzina et al., 2000). Strain Nor $1^{\mathrm{T}}$ differs from Thermanaerovibrio species by the ability to grow chemolithotrophically on $\mathrm{CO}$, producing $\mathrm{H}_{2}$ and $\mathrm{CO}_{2}$, and the phylogenetic distance between Nor $1^{\mathrm{T}}$ strain and Thermanaerovibrio species. A phylogenetic analysis revealed that strain $\operatorname{Nor}^{\mathrm{T}}$ adds to the list of bacterial genera that show Gram-negative-type cell walls but belong to the phylogenetic lineage of Gram-positive bacteria (Lee et al., 1978). By similarity percentage, the closest relative appears to be D. quercicolus (Strömpl et al., 2000). D. quercicolus, formerly Clostridium quercicolum (Stankewich et al., 1971), was isolated from discoloured tissue of living oak trees, and its cells are spore-forming, peritrichously flagellated rods. D. quercicolus is able to ferment fructose or glycerol, producing acetate and propionate. The $\mathrm{G}+\mathrm{C}$ content of its genomic DNA is $52-54 \mathrm{~mol} \%$. Based on consensus tree topology, Selenomonas ruminantium was the

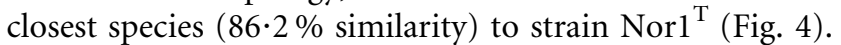
Selenomonas ruminantium is an amino-acid-fermenting anaerobic bacterium, generally found in the digestive tract of mammals (Bryant, 1956). Neither D. quercicolus nor Selenomonas ruminantium was shown to grow on CO.

On the basis of its phenotypic and genotypic properties, we propose strain Norl ${ }^{\mathrm{T}}$ as representative of the type species of a new genus and species, Thermosinus carboxydivorans gen. nov., sp. nov.

\section{Description of Thermosinus gen. nov.}

Thermosinus (Ther.mo.sin' us. Gr. adj. thermos hot; L. masc. n. sinus bend; N.L. masc. n. Thermosinus thermophilic curved rod). 
Cells are motile, curved, non-spore-forming rods. Cell wall of Gram-negative type. Cells divide by binary transverse fission. Obligately anaerobic. Thermophilic. Neutrophilic. Ferment carbohydrates. DNA G + C content is $51 \cdot 7 \pm 1 \mathrm{~mol} \%$. The habitat is terrestrial hot spring.

The type species is Thermosinus carboxydivorans.

\section{Description of Thermosinus carboxydivorans sp. nov.}

Thermosinus carboxydivorans (car.bo.xy.di.vo'rans. N.L. neut. n. carboxydum carbon monoxide; L. part. adj. vorans devouring, digesting; N.L. part. adj. carboxydivorans digesting carbon monoxide).

Has the characteristics of the genus. Cells are curved rods with a length of $2 \cdot 6-3 \mu \mathrm{m}$ and a width of about $0.5 \mu \mathrm{m}$. Motile by means of lateral flagellation. Thermophile, grows in the temperature range $40-68{ }^{\circ} \mathrm{C}$, with an optimum at $60^{\circ} \mathrm{C}$. Neutrophile, grows in the $\mathrm{pH}$ range $6 \cdot 5-7 \cdot 6$, with an optimum at $6 \cdot 8-7 \cdot 0$. Grows on glucose, sucrose, lactose, arabinose, maltose, fructose, xylose and pyruvate, but not on cellobiose, galactose, peptone, yeast extract, lactate, acetate, formate, ethanol, methanol or sodium citrate. During glucose fermentation produces acetate, $\mathrm{H}_{2}$ and $\mathrm{CO}_{2}$. Grows chemolithotrophically on CO. Utilizes $\mathrm{CO}$ as the sole energy source with equimolar formation of $\mathrm{H}_{2}$ and $\mathrm{CO}_{2}$ according to the equation $\mathrm{CO}+\mathrm{H}_{2} \mathrm{O} \rightarrow \mathrm{CO}_{2}+\mathrm{H}_{2}$. Reduces ferric iron during growth on $\mathrm{CO}$, sucrose or lactose. Elemental sulfur, thiosulfate, sulfate and nitrate do not stimulate growth and these are not reduced during growth on CO. Thiosulfate enhances growth rate and cell yield during growth on glucose, sucrose or lactose; in this case, metabolic products are acetate, $\mathrm{H}_{2} \mathrm{~S}$ and $\mathrm{CO}_{2}$. Does not utilize lactate, acetate, formate or $\mathrm{H}_{2}$, neither in the absence nor in the presence of ferric iron, thiosulfate, sulfate, sulfite, elemental sulfur or nitrate. Growth is completely inhibited by penicillin, ampicillin, streptomycin, kanamycin and neomycin. The DNA G + C content is $51 \cdot 7 \pm 1 \mathrm{~mol} \%$.

The type strain is $\operatorname{Nor}^{\mathrm{T}}\left(=\mathrm{DSM} 14886^{\mathrm{T}}=\mathrm{VKM} \mathrm{B}-2281^{\mathrm{T}}\right)$; isolated from a hot pool at Norris Basin, Yellowstone National Park.

\section{ACKNOWLEDGEMENTS}

We are grateful to A. I. Slobodkin, Institute of Microbiology, Russian Academy of Sciences, for fruitful discussion and to S. N. Gavrilov, Institute of Microbiology, Russian Academy of Sciences, for help in the determination of ferrous iron. Samples from the Yellowstone National Park were taken according to permit no. 4056. This work was supported by the NATO LST.CLG. 978269 grant, the CRDF RB2-2379MO-02 grant and the Program 'Molecular and Cell Biology' of the Russian Academy of Sciences. J. M. G. acknowledges support from the Spanish Ministry of Science and Technology through a Ramon y Cajal contract and grant REN2002-00041.

\section{REFERENCES}

Altschul, S. F., Madden, T. L., Schaffer, A. A., Zhang, J., Zhang, Z., Miller, W. \& Lipman, D. J. (1997). Gapped BLAST and PSI-BLAST: a new generation of protein database search programs. Nucleic Acids Res 25, 3389-3402.

Baena, S., Fardeau, M.-L., Woo, T. H. S., Ollivier, B., Labat, M. \& Patel, B. K. C. (1999). Phylogenetic relationships of three aminoacid-utilizing anaerobes, Selenomonas acidaminovorans, 'Selenomonas acidaminophila' and Eubacterium acidaminophilum, as inferred from partial $16 \mathrm{~S}$ rDNA nucleotide sequences and proposal of Thermanaerovibrio acidaminovorans gen. nov., comb. nov. and Anaeromusa acidaminophila gen. nov., comb. nov. Int J Syst Bacteriol 49, 969-974.

Balashova, V. V. \& Zavarzin, G. A. (1980). Anaerobic reduction of ferric iron by hydrogen bacteria. Microbiology (English translation of Mikrobiologiya) 48, 635-639.

Bonam, D., Lehman, L., Roberts, G. P. \& Ludden, P. W. (1989). Regulation of carbon monoxide dehydrogenase and hydrogenase in Rhodospirillum rubrum: effects of CO and oxygen on synthesis and activity. J Bacteriol 171, 3102-3107.

Bryant, M. P. (1956). The characteristics of Selenomonas isolated from bovine rumen contents. J Bacteriol 72, 162-167.

Dobbek, H., Svetlitchnyi, V., Gremer, L., Huber, R. \& Meyer, O. (2001). Crystal structure of a carbon monoxide dehydrogenase reveals a [Ni-4Fe-5S] cluster. Science 293, 1281-1285.

Fardeau, M.-L., Bonilla Salinas, M., L'Haridon, S., Jeanthon, C., Verhé, F., Cayol, J.-L., Patel, B. K. C., Garcia, J.-L. \& Ollivier, B. (2004). Isolation from oil reservoirs of novel thermophilic anaerobes phylogenetically related to Thermoanaerobacter subterraneus: reassignment of $T$. subterraneus, Thermoanaerobacter yonseiensis, Thermoanaerobacter tengcongensis and Carboxydibrachium pacificum to Caldanaerobacter subterraneus gen. nov., sp. nov., comb. nov. as four novel subspecies. Int J Syst Evol Microbiol 54, 467-474.

Felsenstein, J. (1981). Evolutionary trees from DNA sequences: a maximum likelihood approach. J Mol Evol 17, 368-376.

Kevbrin, V. V. \& Zavarzin, G. A. (1992). The influence of sulfur compounds on the growth of halophilic homoacetic bacterium Acetohalobium arabaticum. Microbiology (English translation of Mikrobiologiya) 61, 812-817.

Lee, S. Y., Mabee, M. S. \& Jangaard, N. O. (1978). Pectinatus, a new genus of the family Bacteroidaceae. Int J Syst Bacteriol 28, 582-594. Ludwig, W., Strunk, O., Westram, R. \& 29 other authors (2004). ARB: a software environment for sequence data. Nucleic Acids Res 32, 1363-1371.

Marmur, J. (1961). A procedure for the isolation of desoxyribonucleic acid from microorganisms. J Mol Biol 3, 208-218.

Marmur, J. \& Doty, P. (1962). Determination of the base composition of deoxyribonucleic acid from its thermal denaturation temperature. J Mol Biol 5, 109-118.

Pusheva, M. A. \& Sokolova, T. G. (1995). Distribution of COdehydrogenase activity in anaerobic thermophilic carboxydotrophic bacterium Carboxydothermus hydrogenoformans grown at the expense of $\mathrm{CO}$ or pyruvate. Microbiology (English translation of Mikrobiologiya) 64, 491-495.

Sokolova, T. G., Gonzalez, J. M., Kostrikina, N. A., Chernyh, N. A., Tourova, T. P., Kato, C., Bonch-Osmolovskaya, E. A. \& Robb, F. T. (2001). Carboxydobrachium pacificum gen. nov., sp. nov., a new anaerobic, thermophilic, CO-utilizing marine bacterium from Okinawa Trough. Int J Syst Evol Microbiol 51, 141-149.

Sokolova, T. G., Kostrikina, N. A., Chernyh, N. A., Tourova, T. P., Kolganova, T. V. \& Bonch-Osmolovskaya, E. A. (2002). Carboxydocella thermautotrophica gen. nov., sp. nov., a novel 
anaerobic, CO-utilizing thermophile from Kamchatkan hot spring. Int J Syst Evol Microbiol 52, 1961-1967.

Sokolova, T. G., Jeanthon, C., Kostrikina, N. A., Chernyh, N. A., Lebedinsky, A. V., Stackebrandt, E. \& Bonch-Osmolovskaya, E. A. (2004). The first evidence of anaerobic CO oxidation coupled with $\mathrm{H}_{2}$ production by a hyperthermophilic archaeon isolated from a deep-sea hydrothermal vent. Extremophiles 8, 317-323.

Stankewich, J. P., Cosenza, B. J. \& Shigo, A. L. (1971). Clostridium quercicolum sp. n., isolated from discolored tissues in living oak trees. Antonie van Leeuwenhoek 37, 299-302.

Strimmer, K. \& von Haeseler, A. (1996). Quartet puzzling: a quartet maximum-likelihood method for reconstructing tree topologies. Mol Biol Evol 13, 964-969.

Strömpl, C., Tindall, B. J., Lunsdorf, H., Wong, T. Y., Moore, E. R. \& Hippe, H. (2000). Reclassification of Clostridium quercicolum as Dendrosporobacter quercicolus gen. nov., comb. nov. Int J Syst Evol Microbiol 50, 101-106.

Svetlichny, V. A., Sokolova, T. G., Gerhardt, M., Ringpfeil, M., Kostrikina, N. A. \& Zavarzin, G. A. (1991). Carboxydothermus hydrogenoformans gen.nov., sp.nov., a CO-utilizing thermophilic anaerobic bacterium from hydrothermal environments of Kunashir Island. Syst Appl Microbiol 14, 254-260.
Svetlichny, V. A., Sokolova, T. G., Kostrikina, N. A. \& Lysenko, A. M. (1994). A new thermophilic anaerobic carboxydotrophic bacterium Carboxydothermus restrictus sp. nov. Microbiology (English translation of Mikrobiologiya) 3, 294-297.

Svetlitchny, V., Peschel, C., Acker, G. \& Meyer, O. (2001). Two membrane-associated NiFeS-carbon monoxide dehydrogenases from the anaerobic carbon-monoxide-utilizing eubacterium Carboxydothermus hydrogenoformans. J Bacteriol 183, 5134-5144.

Trüper, H. G. \& Schlegel, H. G. (1964). Sulfur metabolism in Thiorhodaceae. Quantitative measurements on growing cells of Chromatium okenii. Antonie van Leeuwenhoek 30, 225-238.

Uffen, R. L. (1976). Anaerobic growth of Rhodopseudomonas species in the dark with carbon monoxide as sole carbon and energy substrate. Proc Natl Acad Sci U S A 73, 3298-3302.

Wolin, E. A., Wolin, M. J. \& Wolfe, R. S. (1963). Formation of methane by bacterial extracts. J Biol Chem 238, 2882-2886.

Zavarzina, D. G., Zhilina, T. N., Tourova, T. P., Kuznetsov, B. B., Kostrikina, N. A. \& Bonch-Osmolovskaya, E. A. (2000). Thermanaerovibrio velox sp. nov., a new anaerobic, thermophilic, organotrophic bacterium that reduces elemental sulfur, and emended description of the genus Thermanaerovibrio. Int J Syst Evol Microbiol 50, 1287-1295. 